\title{
Exploring the Causes of Listening Comprehension Anxiety from EFL Saudi Learners' Perspectives: A Pilot Study
}

\author{
Ibrahim Otair ${ }^{*}$, Noor Hashima Abd Aziz ${ }^{2}$ \\ ${ }^{1}$ UUM CAS, Universiti Utara Malaysia, 06010 Sintok, Kedah, Malaysia \\ ${ }^{2}$ Department of Language Studies, School of Languages, Civilisation \& Philosophy, UUM CAS, \\ Universiti Utara Malaysia, 06010 Sintok, Kedah, Malaysia
}

Corresponding Author: Ibrahim Otair, E-mail: ibrahimotair@yahoo.com

\section{ARTICLE INFO}

Article history

Received: June 02, 2017

Accepted: July 29, 2017

Published: August 31, 2017

Volume: 8 Issue: 4

Advance access: August 2017

Conflicts of interest: None

Funding: None

\section{Key words:}

Semi-Structured Interviews,

Listening Comprehension Anxiety,

Pilot Study,

English As a Foreign Language (EFL),

Saudi Learners

\begin{abstract}
Anxiety is an important factor in foreign language learning. Very few studies have been done on English as a Foreign Language (EFL) Saudi students in listening classes. Therefore, this pilot study was aimed at exploring the causes of listening comprehension anxiety from EFL Saudi learners' perspectives at Majmaah University, Saudi Arabia. The pilot study involved two students who were selected based on the following criteria: 1) Only Saudi male undergraduate students who enrolled in Preparatory Year Program (PYP) at Majmaah University would be involved in this study, 2) The students who had studied or lived in native English speaking countries would be excluded. The researcher used pseudonyms to refer to the participants as Mohammad and Ismail. This study employed a qualitative case study research design. The data were collected through Semi-structured interviews with the participants. The interview sessions were audiotaped and transcribed. The results show that the participants experienced a high level of anxiety when doing the listening comprehension tasks. Three main causes of listening comprehension anxiety emerged from this study: 1) the problematic nature of listening comprehension, 2) the classroom atmosphere, and 3) the low English proficiency of the students.
\end{abstract}

\section{INTRODUCTION}

Most English as a foreign language (EFL) learners face serious problems when listening to English language tasks because they have to understand and comprehend what the speaker says (Vogely, 1999). In addition, listening skill requires hypothesizing, prediction, generalizing, revising and checking for the listening inputs (Vandergrift, 1997). A major problem related to listening comprehension is anxiety. Several researchers (Kim, 2000; Kimura, 2008; Vogely, 1998) agree that anxiety hinders the process of language learning especially among EFL learners. Language anxiety is defined as "the feeling of tension and apprehension, specifically associated with second language contexts, including speaking, listening, and learning" (Maclntyre and Gardner, 1994, p.24). This paper is on the pilot study of a Doctoral thesis that the researcher conducted in order to explore the listening comprehension anxiety among EFL Saudi learners.

Some researchers (Kimura, 2008; Ko, 2010; Lili, 2016) argue that in order to understand the phenomenon of foreign language anxiety, language skills should be studied separately. Research done on specific language skill anxiety are writing (Cheng, 2004), speaking (Abdullah and Rahman, 2010), listening (Elkhafaifi, 2005) and reading (Al-Shboul,
Ahmad, Nordin and Rahman, 2013). Although research on language anxiety have found that speaking skill provokes the most anxiety, listening comprehension anxiety has also been considered as a problematic area for EFL learners (Young, 1992). In listening, the learners face difficulties in comprehending the speech. They receive the information just once and in restricted procedures then they are supposed to answer directly the questions posed (Vogely, 1999).

Let us start with the definition of listening comprehension anxiety in order to understand this phenomenon. Wheeless (1975) describes listening comprehension anxiety as "a receiver's apprehension, fear of misinterpretation, inadequately processing or not being able to adjust psychologically to messages sent by others" (p.263). In addition, Elkhafaifi (2005) believes that listening comprehension anxiety is the feeling of fear and nervousness of listening to a foreign language.

Listening comprehension anxiety is important because studies that have been conducted found anxiety to hinder listening comprehension process and cause serious problems for EFL learners. Students' performance, achievement, proficiency and other variables are associated with anxiety in relation to listening comprehension (Moghadam, Ghanizadeh 
and Akbari, 2015). Krashen (1985) states that the language learning process can be influenced by affective factors such as anxiety, motivation, attitude and self-confidence. He defines the affective factors as filters which can monitor the process of language acquisition through permitting the language input to pass into the language learning systems in the mind. He also explains that anxiety works as blocks that prevent the information to reach into the specific areas in the brain.

A number of studies have been done to identify the causes of listening comprehension anxiety among EFL learners. The findings of those studies found many causes for listening comprehension anxiety which are linked to the characteristics of listening tasks (Vogely,1998), using traditional classroom instruction (Elkhafaifi,2005). Scarcella and Oxford (1992) reported that unfamiliarity with listening tasks and lack of English language proficiency of the students to be the major causes of listening comprehension anxiety. In addition, Gonen (2009) found that causes such as speed of speech, lack of clarity, characteristics of the listening text and lack of visualization lead to listening comprehension anxiety. Kim (2000) also reported that text characteristics, personal characteristics and process-related characteristics were the main reasons of listening comprehension anxiety. Other studies (Chang, 2008; Golchi, 2012) discussed the causes of listening comprehension anxiety from the cognitive and linguistics perspectives. They found some causes that could relate to listening anxiety were lack of understanding listening process, lack of self-confidence and lack of role models

Studies on listening comprehension anxiety are limited in number. Some researchers argue that not much attention has been given to listening comprehension anxiety (Arnold, 2000; Gojion, 2014; Moghadam, et al, 2015). Krashen (1985) highlights that research relating to listening comprehension anxiety are limited in spite of listening comprehension in foreign language learning has been found to be highly anxiety provoking. Moreover, although previous studies on listening comprehension anxiety focused on the potential causes and effects, the question remains as to how anxiety is associated with listening comprehension in foreign language learning (Kimura, 2008). Therefore, research on listening comprehension anxiety is needed and this study tries to fill in this gap.

Kim (2000) states that the causes and effects of listening comprehension anxiety vary depending on the population and culture. Thus, more studies on different population and cultures may give new insights on listening comprehension anxiety. Most studies on listening comprehension anxiety have been conducted on students from the western countries. Therefore, there is a lack of research on other parts of the world, especially the Arab countries (Al-Shboul et al 2013). EFL Saudi learners like other in all over the world may have difficulties in listening. Hence, this study focused on EFL Saudi students.

Dewaele and Al-Saraj (2013) found that one of the main problems that Saudi students faced was related to anxiety. In their study on Arab women studying in English preparatory program at a college in Saudi Arabia they found that teach- er-student interactions and teacher behavior contributed to anxiety among the learners. Only few studies have directly focused on listening comprehension anxiety in Saudi Arabia. Alrabai (2014) proposes that more research on a specific language skill is needed to investigate anxiety which may lead to new insights and how anxiety problems can be reduced.

Similarly, from the researcher's experience teaching English language skills to EFL Saudi learners specifically listening and speaking skills, a majority of the students who had enrolled in PYP at Majmaah University were found to be anxious. This was obvious with the students who attended listening classes. Studies have been carried out in Saudi Arabia which focus on foreign language anxiety and listening comprehension problems such as Alrabai (2014); Dewaele and Al-Saraj (2013); Javid (2014). Very few studies have been conducted specifically on listening comprehension anxiety. Therefore, the aim of this pilot study is to explore the causes of listening comprehension anxiety for the EFL Saudi learners.

\section{THEORETICAL FRAMEWORK}

Many models and theories discuss the role of language anxiety in language learning process. Among those theories, the researcher has chosen two prominent models which are found to be relevant to this study on listening comprehension anxiety.

\section{Maclntyre and Gardner's Model of the Role of Anxiety in Language Learning}

Maclntyre and Gardner (1991) developed a model to describe anxiety in language learning and how language anxiety is developed. This model proposes three phases that are involved in the language learning in relation to anxiety: beginner, post-beginner and later phase. At the first phase, anxiety does not affect the language learning process because it is not specific to language learning. At the second one, the learners start developing attitudes and emotions specifically to the second language learning context. When the learners had negative experience in language learning, then anxiety begins to develop and they also might achieve low performance in the language learning. At the later phase, when the learners continue to have negative experience, then their anxiety level will increase, and this will lead to poor performance in the language learning.

\section{Trait-state Theory}

Spielberger (1972) proposes the Trait-State Theory to illustrate the anxiety phenomenon. This theory does not explain language anxiety in details but it provides some ideas on anxiety which can be applied. The theory proposes that anxiety is experienced when a learner thinks or judges that a situation is risky. The cognitive appraisal of a situation comes from internal and external stimuli. The internal stimuli are thoughts, feelings, and biological needs. According to this theory, the internal stimuli are expected to affect the language learning process. This theory could be beneficial in 
explaining the causes of listening comprehension anxiety to be discussed in the research question of this study.

\section{METHODOLOGY}

\section{Research Design}

The researcher has chosen a qualitative research approach to help him explore the causes of listening comprehension anxiety phenomenon. Since a qualitative research is used to explore people's feelings, perceptions and beliefs, this approach is suitable to this study (Creswell, 2012). Furthermore, a qualitative research is also used to understand a certain problem in specific details. In this study, the researcher wants to give a detailed understanding of the causes of listening comprehension anxiety. A qualitative case study design has been selected to answer the research questions because a case study is used when the boundaries of the phenomenon is not clearly evident (Yin, 2009). Research on listening comprehension anxiety have not found any clear evidence for the causes of anxiety when students are listening to English language tasks (Serraj, 2015).

\section{Participants}

In a qualitative study, the main purpose of sampling is to find individuals who can give new insights into the phenomenon under investigation (Dornyei, 2007). For this pilot study, the researcher used purposive sampling to select EFL Saudi students as participants because they were available, compatible, and had some characteristics the researcher sought to study (Creswell, 2002). Careful considerations were taken in order to choose suitable participants using the following criteria: 1) Only Saudi undergraduate students who enrolled in Preparatory Year Program (PYP) at Majmaah University would be involved in this study, 2) Only male students would be included in the study because in Arabic culture especially Saudi Arabia, men are not allowed to meet women face to face, 3) The students who had studied or lived in native English speaking countries would be excluded.

\section{Data Collection}

The data were collected through semi-structured interviews with two participants. The interviews were carried out at the library of Majmaah University, face to face with each participant. Semi-structured interviews were used to understand in details about the participants' perspectives toward listening comprehension anxiety. Each interview took about 15 to 25 minutes and was audio-taped. The semi-structured interviews consisted of 15 questions (please refer to Appendix 1). The interview questions were adapted from other related studies but some questions were written by the researcher himself after consulting his supervisor.

\section{Data Analysis}

In this study, the data were derived from the verbatim transcriptions of the interviews. The interviews were recorded, transcribed and double checked with the note-taking. The researcher used step by step guidelines for thematic analysis which have been proposed by Braun and Clarke (2006). The following steps were: 1) getting familiar with your data, 2) creating initial codes, 3) looking for themes, 4) criticizing the themes, 5) specifying and naming the themes, and 6) generating the report. Three themes emerged from the interview data: 1) the problematic nature of listening comprehension, 2) the classroom atmosphere, and 3) the low English proficiency of the students

\section{FINDINGS}

\section{Mohammad}

The first interview was carried out with Mohammad who was a student at the College of Medical Sciences, Majmaah University.

\section{The problematic nature of listening comprehension}

With regards to the research question on the causes of anxiety when trying to complete the listening tasks in English language, Mohammad replied that the difficulties were related to the speed of speech, strange accents of the speakers, limited time given and lose of concentration in the long conversation. He mentioned instances where the speaker was speaking very fast he would lose his concentration and thus it made him anxious. In addition, he believed that the different accents had misled him during the listening tasks.

\section{The classroom atmosphere}

In replying to questions related to the classroom atmosphere of listening classes, Mohammad mentioned that he was afraid of being laughed at by his colleagues if they found out that he didn't understand the listening tasks in the class. He also added that competition among the students made him under pressure. Mohammad mentioned other causes of anxiety related to the classroom were lack of clarity, noisy, listening examination atmosphere and proctors or teachers. He admitted that when the proctors were tough, the students would be more anxious and stressful.

\section{The low English proficiency of students}

A few questions were asked about the level of the students' proficiency in English language. For instance, when the researcher asked questions on the English proficiency of the students, Mohammad answered that majority of the students come from rural areas, so they did not attend good schools. The teachers at their schools did not focus on the four English language skills. They only taught the students reading and writing skills. Mohammad admitted that when studying at Majmaah University, he faced difficulties to do listening skill tasks because it was something new. Additionally, he stated that he was unfamiliar with many English words. Other causes of listening comprehension anxiety mentioned by Mohammad were the lack of knowledge about listening 
skill, negative self-perception about listening skill, getting low marks and low English proficiency of the students

\section{Ismail}

The second interview was conducted with Ismail who was a student at the College of Engineering, Majmaah University.

\section{The problematic nature of listening comprehension}

Ismail's responses to the questions related to his feeling and attitudes towards listening comprehension in English were negative. Ismail associated many causes of the listening comprehension difficulties to the feeling of anxiety among the students. He stated that when listening to recordings in the classroom that he could not decipher the speech, he felt anxious because he was allowed to listen to the speech only once. He also had difficulty in understanding some English accents. He found long conversations to be difficult because he would lose his concentration and could not stay focused. Ismail also felt anxious because of the short period of time given to answer the listening questions. He ended his responses by saying that the nature of listening comprehension is problematic. Listening comprehension skill is not like other skills, such as reading and writing where the students have time to recall and think about the questions posed.

\section{The classroom atmosphere}

Ismail's responses to the questions regarding the classroom atmosphere of listening classes were negative. When the researcher asked Ismail about the atmosphere in his classroom and its role in listening comprehension anxiety, he replied that his colleagues compete with each other and that made him anxious. He also mentioned that sometimes the sound from the recording was unclear and some students made noise in the class. He sometimes lost face when discussing the listening task with his peers because he did not understand the speech clearly. Ismail admitted that the listening examination atmosphere led to anxiety because the students were afraid of failure.

\section{The low English proficiency of students}

Ismail attributed his listening comprehension problem to his low proficiency level in English. He stated that he was weak in English. He studied at a high school which did not focus on learning vocabulary. He also did not have any listening classes of English at school. He admitted that during the English listening tasks he was unable to deal with them and did not know how to complete the tasks correctly. Finally, he added that getting low marks made him more anxious.

\section{CONCLUSION AND DISCUSSION}

From the pilot study, the researcher found that the participants had difficulties in understanding the interview questions because they had to speak in English language. Therefore, when answering the questions they used Arabic to be precise in their explanation. Both participants experienced a high anxiety in listening to spoken English. This finding can be associated with Krashen's findings that listening "is highly anxiety provoking if [the discourse] is incomprehensible" (cited in Young, 1992, p. 168).

Mohammad and Ismail admitted that listening comprehension in English is problematic in nature. The strange accents and the speed of speech made the two participants lose their concentration, thus this made them anxious. In addition, they stated that anxiety could be attributed to the limited time given to complete the listening tasks. They faced problem to recall the information they listened earlier in order to answer the examination questions because the time given was limited and the recording was not repeated. This can be linked to Arnold's (2000) findings that listening is a receptive skill involving serious time constraints on process which can be very stressful for students.

In terms of classroom atmosphere, the two participants explained how the classroom atmosphere could lead to listening comprehension anxiety for them. They mentioned that the competition among the students led to stress and afraid of being laughed at by others also could provoke anxiety. Other causes mentioned by them were lack of clarity and noisy which could be stressful for the students. These findings are similar to the ones found by Serraj (2015). Serraj found that the major causes of listening anxiety were input factor (lack of time to process, nature of speech) and environmental factors (class environment, peers).

Both participants also admitted that they were weak in English proficienc. Their English vocabulary was limited. Therefore, they had problem in comprehending the listening tasks which led to their low marks. The lack of experience and knowledge were other problem for them. They had no idea about listening strategies and how to employ them during the listening tasks. They also had negative self-perception about listening skill. This can be linked to Vogely's (1999) finding that some teachers were unaware about listening exercises and they did not provide enough listening strategies for their students. Moreover, these findings can be associated with Joiner's (1986) finding that anxiety related to listening can come from a negative self-confidence level in listening skill. To sum up, this pilot study found three causes of listening comprehension anxiety: 1) the problematic nature of listening comprehension, 2) the classroom atmosphere, and 3) the low English proficiency of the students

\section{REFERENCES}

Abdullah, K., \& Rahman, N. (2010). A study on second language speaking anxiety among UTM students. Universiti Teknologi Malaysia Institutional Repository, 1-6. Retrieved from http:/www.fp.utm.my/epusatsumber/ pdffail/ptkghdfwp2/p_2009_8820.

Alrabai, F. (2014). A model of foreign language anxiety in the Saudi EFL context. English Language Teaching, 7(7),82. DOI: http://dx.doi.org/10.5539/elt.v7n7p82.

Al-Shboul, M. M., Ahmad, I. S., Nordin, M. S., \& Rahman, Z. A. (2013). Foreign language reading anxiety in a Jordanian EFL context: A qualitative study. En- 
glish Language Teaching, 6(6), 38. DOI: 10.5539/elt. v6n6p38.

Arnold, J. (2000). Seeing through listening comprehension exam anxiety. TESOL Quarterly, 34(4), 777-786. doi: $10.2307 / 3587791$.

Braun, V., \& Clarke, V. (2006). Using thematic analysis in psychology. Qualitative Research in Psychology, 3(2), 77-101. Retrieved from http://eprints.uwe.ac.uk/11735.

Chang, A. C. S. (2008). Sources of listening anxiety in learning English as a foreign language. Perceptual and Motor Skills, 106(1), 21-34.

Cheng, Y. S. (2004). A measure of second language writing anxiety: Scale development and preliminary validation. Journal of Second Language Writing, 13(4), 313335. DOI: 10.1016/j.jslw.2004.07.001.

Creswell, J. W. (2002). Educational research: Planning, conducting, and evaluating quantitative. Upper Saddle River, NJ: Prentice Hall.

Creswell, J. W. (2012). Educational research: Planning, conducting, and evaluating quantitative and qualitative research ( $4^{\text {th }}$ ed.). Boston: Pearson Education.

Dewaele, J. M., \& Al-Saraj, T. M. (2013). Foreign Language Anxiety: Some conceptual and methodological issues. Journal of Psychology, 68 (3), 71-78. DOI: http:// dx.doi.org/10.14746/ssllt.2015.5.2.2.

Dörnyei, Z. (2007). Research methods in applied linguistics: Quantitative, qualitative, and mixed methodologies. Oxford, England: Oxford University Press.

Elkhafaifi, H. (2005). Listening comprehension and anxiety in the Arabic language classroom. The Modern Language Journal, 89(2), 206-220. DOI: 10.1111/j.15404781.2005.00275.x.

Gojian, B. (2014). Effect of Anxiety Awareness on Listening Comprehension. Journal of International Scientific Publications, 12, 1057-1064. Retrieved from http:// www.ccseet.org/journal/index.php/ijel/article/download/17093/12699.

Golchi, M. M. (2012). Listening anxiety and its relationship with listening strategy use and listening comprehension among Iranian IELTS learners. International Journal of English Linguistics, 2(4), 115.

Gonen, M. (2009, July). The relationship between FL listening anxiety and FL listening strategies: The case of Turkish EFL learners. In Proceedings of the $5^{\text {th }}$ WSEAS/ IASME International conference on educational technologies (pp. 44-49).

Javid, C. Z. (2014). Measuring language anxiety in an EFL context. Journal of Education and Practice, 5(25),180193. Retrieved from http://www.iiste.org/Journals/index.php/RHSS/article/view/12477.

Joiner, E. (1986). Listening in the Foreign Language, in B. H. Wing(Ed.), Listening Reading, and Writing: Analysis and Application. Middlebury, VT: Northeast Conference on the Teaching of Foreign Languages (pp.43-70).Vermont, US.

Kim, J. H. (2000). Foreign language listening anxiety: A study of Korean students learning English. English Teaching, 57(2), 3-34. Retrieved from http://journal. kate.or.kr/wp-content/uploads/2015/02/kate 57221 . pdf.

Kimura, H. (2008). Foreign language listening anxiety: Its dimensionality and group differences. JALT Journal, 30(2), 173-196. Retrieved from https://jalt- publications.org/files/pdf-article/art2_7.pdf

Ko, Y. A. (2010). The effects of pedagogical agents on listening anxiety and listening comprehension in an English as a foreign language context (Doctoral dissertation, UtahState University, Utah, US. Retrieved from http:// digitalcommons.usu.edu/cgi.

Krashen, S. D. (1985). The Input Hypothesis: Issues and Implications. New York: Longman.

Lili, Z. (2016) Influence of anxiety on English listening comprehension: An investigation based on the freshman of English majors. Studies in Literature and Language, 11(6), 40-47. Retrieved from http://www.cscanada.net/ index.php/sll/article/download/7952/8823.

MacIntyre, P. D., \& Gardner, R. C. (1991). Methods and results in the study of anxiety and language learning: A review of the literature. Language learning, 41(1), 85-117.

MacIntyre, P. D., \& Gardner, R. C. (1994). The subtle effects of language anxiety on cognitive processing in the second language. Language learning, 44(2), 283-305.

Moghadam, S. B., Ghanizadeh, A., \& Akbari, O. (2015). The Effect of Bilingualism on the Listening Strategies and Listening Anxiety among Iranian Junior High School Students. Journal of Applied Linguistics and Language Research, 2(4), 236-248. Retrieved from http://www. jallr.com/index.php/JALLR/article/download/76/pdf.

Scarcella, R. C., \& Oxford, R. L. (1992). The tapestry of language learning: The individual in the communicative classroom (p. 63). Boston: Heinle \& Heinle.

Serraj, S. (2015). Listening Anxiety in Iranian EFL learners. International Journal of Scientific and Research Publications, 5(6). Retrieved from http://www.ijsrp.org/ research-paper-0615/ijsrp-p4285.pdf.

Spielberger, C. D. (1972). Conceptual and methodological issues in anxiety research. In C. D. Spielberger (Ed.), Anxiety: Current trends in theory and research $\left(2^{\text {nd }} \mathrm{ed}\right.$., pp. 481-493). New York, US.

Vandergrift, L. (1997). The comprehension strategies of second language (French) listeners: A descriptive study. Foreign Language Annals, 30(3), 387-409. DOI: 10.1111/j.1944-9720.1997.tb02362.x.

Vogely, A. J. (1998). Listening comprehension anxiety: Students' reported sources and solutions. Foreign Language Annals, 31(1), 67-80.

Vogely, A. (1999). Addressing listening comprehension anxiety. In D. J. Young (Eds.), Affect in foreign language and second language learning. A practical guide to creating a low-anxiety atmosphere (pp. 106-123). Boston: McGraw-Hill

Wheeless, L. R. (1975). An investigation of receiver apprehension and social context dimensions of communication apprehension. Communication Education, 24(3), 261-268. Retrieved from http:/www.tandfonline.com/ doi/abs/10.1080/03634527509378169. 
Yin, R. K. (2009). Case study research: Design and Methods. SAGE publications. Thousand oaks.

Young, D. J. (1992). Language anxiety from the foreign language specialist's perspective: Interviews with
Krashen, Omaggio Hadley, Terrell, and Rardin. Foreign Language Annals, 25(2), 157-172. Retrieved from www.ccsenet.org/journal/index.php/ijel/article/download/15522/11842.

\section{APPENDIX}

\section{Interview Questions}

1. What is your name?

2. How old are you?

3. Where do you live?

4. What is your major?

5. Have you studied in a native country of English?

6. Which language skill (listening, reading, writing, and speaking) do you consider as the most difficult? Why?

7. What do you usually prefer to listen to? Probes: movies, lectures, or song.

8. Please, describe your experience of learning "listening comprehension".

9. How do you feel when you listen to listening tasks or activities?

10. What makes listening tasks difficult for you

11. Have you experienced anxiety while doing English listening tests in the classroom?

12. At what level do you rate your listening comprehension anxiety in English? Probes: "low, average, or high".

13. What kind of English listening comprehension tasks make you anxious?

14. In which situations or tasks do you feel less anxious and perform better in listening comprehension?

15. What factors do you think have contributed to your anxiety in comprehending listening tasks in English language? 